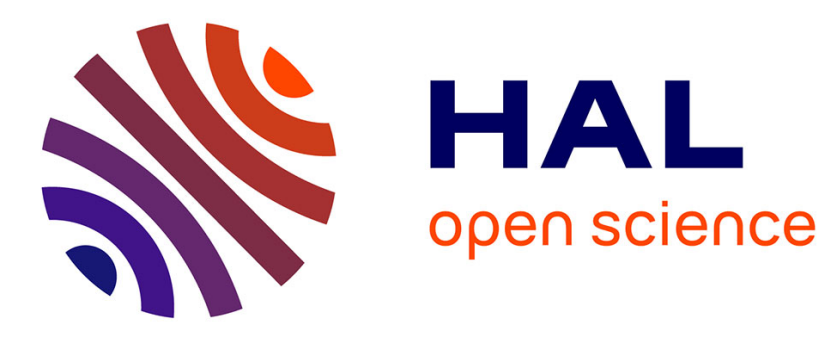

\title{
Wild-type VHL Clear Cell Renal Cell Carcinomas Are a Distinct Clinical and Histologic Entity: A 10-Year Follow-up
}

Julien Dagher, Solene-Florence Kammerer-Jacquet, Angélique Brunot, Adélaide Pladys, Jean-Jacques Patard, Karim Bensalah, Christophe Perrin, Gregory Verhoest, Jean Mosser, Alexandra Lespagnol, et al.

\section{To cite this version:}

Julien Dagher, Solene-Florence Kammerer-Jacquet, Angélique Brunot, Adélaide Pladys, Jean-Jacques Patard, et al.. Wild-type VHL Clear Cell Renal Cell Carcinomas Are a Distinct Clinical and Histologic Entity: A 10-Year Follow-up. European Urology Focus, 2016, 1 (3), pp.284-290. 10.1016/j.euf.2015.06.001 . hal-01165106

\section{HAL Id: hal-01165106 \\ https://hal-univ-rennes1.archives-ouvertes.fr/hal-01165106}

Submitted on 16 Sep 2015

HAL is a multi-disciplinary open access archive for the deposit and dissemination of scientific research documents, whether they are published or not. The documents may come from teaching and research institutions in France or abroad, or from public or private research centers.
L'archive ouverte pluridisciplinaire HAL, est destinée au dépôt et à la diffusion de documents scientifiques de niveau recherche, publiés ou non, émanant des établissements d'enseignement et de recherche français ou étrangers, des laboratoires publics ou privés. 


\section{TITLE PAGE}

Wild type $V H L$ clear cell renal cell carcinomas are a distinct clinical and histological entity. A ten-year follow up.

Julien Dagher* ${ }^{1,2}$, Solène-Florence Kammerer-Jacquet* ${ }^{1,2}$, Angélique Brunot ${ }^{3}$, Adélaide Pladys $^{1}$, Jean-Jacques Patard ${ }^{4}$, Karim Bensalah ${ }^{5}$, Christophe Perrin ${ }^{3}$, Grégory Verhoest ${ }^{5}$, Jean Mosser $^{6}$, Alexandra Lespagnol ${ }^{6}$, Cécile Vigneau ${ }^{1,7}$, Frédéric Dugay ${ }^{1,8}$, Marc-Antoine BelaudRotureau $^{1,8}$, Nathalie Rioux-Leclercq ${ }^{1,2}$.

*These authors contributed equally to the work and are considered as co-first authors.

1. CNRS/UMR 6290 Biosit, Faculté de Médecine de Rennes1, 35043 Rennes, France

2. Service d'Anatomie et Cytologie Pathologiques, CHU Rennes, 35033 Rennes, France

3. Service d'Oncologie Médicale, Centre Eugène Marquis, 35042 Rennes, France

4. Service d'Urologie, CHU Kremlin Bicêtre, Université de Paris 9, Paris, France

5. Service d'Urologie, CHU Rennes, 35033 Rennes, France

6. Service de Génétique Moléculaire et Génomique, CHU Rennes, 35033 Rennes, France

7. Service de Néphrologie, CHU Rennes, 35033 Rennes, France

8. Service de Cytogénétique et Biologie Cellulaire, CHU Rennes, 35033, France 


\section{Corresponding author}

Julien Dagher

Service d'Anatomie et Cytologie Pathologiques, CHU Pontchaillou, 2 rue Henri le Guilloux, 35033 Rennes Cedex 9, France

Tél : +33673608062

Fax : +33299284284

Email : julien.dagher@chu-rennes.fr

\section{Keywords}

Clear cell renal carcinoma; Kidney cancer; Pathology; Prognosis; Survival; VHL.

Word count: text: 2792 words. 


\begin{abstract}
Background: Clear cell renal cell carcinoma (ccRCC) is an aggressive tumor with $50 \%$ risk of metastases at initial diagnosis or at follow-up. An inactivation of the tumor suppressor gene VHL is present in more than $70 \%$ of sporadic cases by two of three different mechanisms: locus deletion, gene mutation or promoter hypermethylation.
\end{abstract}

Objective: To correlate the complete status of the VHL gene with clinical and pathological criteria.

Design, Setting, and Participants: We retrospectively included 98 ccRCCs operated between 2002 and 2005. VHL gene deletions $(71 / 98,72.4 \%)$, mutations $(68 / 98,69.4 \%)$ and promoter hypermethylations $(13 / 98,13.3 \%)$ were screened by gene copy analysis, gene sequencing and Methylation Specific-MLPA respectively.

Outcome Measurements and Statistical Analysis: Relationships between VHL subgroups and the studied criteria were analyzed using $x 2$ and Student's tests. Survival using log rank test and Kaplan Meier curves.

Results and Limitations: Compared to ccRCCs with 2 events (66.3\%), tumors with 0 or 1 genetic event $(33.6 \%)$ were associated with a higher nuclear grade $4(\mathrm{p}=0.02)$, metastases $(\mathrm{p}=0.04)$, sarcomatoid component $(\mathrm{p}=0.01)$, dense lymphocyte infiltrate $(\mathrm{p}=0.013)$ and to VEGF overexpression $(>30 \%)(\mathrm{p}=0.003)$, which was also an independent factor after multivariate analysis. Furthermore, wild type VHL tumors (no inactivating event, 11.2\%) were associated with nodal involvement ( $\mathrm{p}=0.019)$, and had a specific survival of 33 months compared to patients with ccRCCs having 1 or 2 VHL inactivating events (107 months) (p $=0.016$ ). The retrospective design with small number of wild type tumors was a limitation to this work. 
Conclusions: This long term study (10-year clinical follow-up) confirms that ccRCCs with wild type $V H L$ are highly aggressive tumors that need to be formerly identified.

Patient Summary: Among activated VHL tumors, the wild type subgroup defines an aggressive phenotype with worse survival rates, suggesting that these tumors must be more thoroughly screened. 


\section{TEXT}

\section{INTRODUCTION}

Renal cell carcinoma accounts for $3 \%$ of incidental solid tumors, of whom $70 \%$ to $75 \%$ are clear cell renal cell carcinomas (ccRCC) which are highly vascularized tumors. VHL is a major tumor suppressor gene involved in renal carcinogenesis. Alterations englobing its locus on chromosome 3p25-p26 in ccRCCs have been first described in patients with Von Hippel Lindau disease but VHL gene abnormalities are also observed in $60 \%$ to $70 \%$ of sporadic ccRCCs [1-3]. These genetic alterations are specific of the clear cell subtype and are typically not associated with other histological subtypes of renal carcinoma [4].

At a cellular level, VHL acts as a tumor-suppressor gene. Its protein, pVHL, is a multifunctional protein insuring variable regulatory functions such as remodeling extra cellular matrix and controlling the cell cycle. The function that has been most thoroughly studied is the stability regulation of hypoxia inductible factor (HIF). pVHL is a component of an E3 ubiquitin-ligase which targets proteins, including the transcription factor HIF, leading to their ubiquitination and degradation by proteasomes. The consequence of pVHL impairment is a stabilization and increased level of HIF, leading to the transcription of genes regulated by HIF such as vascular endothelial growth factor (VEGF) or carbonic anhydrase IX $(C A I X)$ [5]. Consequently, VHL acts as one of the main triggers of the angiogenic processes in ccRCC.

VHL gene impairments described in ccRCC necessarily involve biallelic alterations in tumor cells as both first and second "hits" must occur to be inactivated. These may reflect either mutations or deletions of the gene and/or hypermethylation of its promoter. One third of ccRCCs however exhibit no or a single allele alteration of VHL. Even if its key role is not 
completely elucidated, the association between $V H L$ alterations and ccRCC carcinogenesis is well admitted at an early stage.

In this study, we aimed to perform a detailed analysis of the VHL status in a retrospective cohort of ccRCCs in correlation with pathological criteria and long term clinical outcomes. Our main goal was to seek differences in histological aspects depending on the complete $V H L$ gene status. Our second objective was to verify if a given VHL group was associated with a worse prognosis, which was clinically relevant as the duration of our follow-up was a decade long. 


\section{MATERIALS AND METHODS}

\section{$\underline{\text { Patients }}$}

Patients operated for sporadic ccRCC in the Department of Urology at Rennes Hospital between 2002 and 2005 were retrospectively included. Care following surgery complied with standard recommendations for the given period, and patients' clinical conditions were monitored by the ECOG scale [6]. The study protocol was approved by the local advisory board and informed consent was obtained from each patient.

\section{$\underline{\text { Tissue sample management }}$}

All consecutive and histologically validated ccRCCs were analyzed. Immediately after macroscopic examination, small samples were collected from surgical specimens and stored at $-80^{\circ} \mathrm{C}$ until DNA extraction, using QIAamp DNA minikit (Qiagen, Courtaboeuf, France). DNA quantity and quality were estimated by optical density (OD 260/280) measurement and $0,8 \%$ agarose gel electrophoresis using standard protocols.

\section{$\underline{\text { Pathological analysis }}$}

After fresh tissue sampling, surgical specimens were formalin-fixed. Paraffin sections were stained with hematoxylin and eosin-safran. The analyzed parameters were: tumor size, multifocality, nuclear grade, sarcomatoid pattern, tumor necrosis, granular component, lymphocyte infiltrate and microvessel invasion. Tumor stage was defined according to the latest International Union Against Cancer 2009 classification [7].

\section{$\underline{\text { Immunochemistry }}$}

For each case, a representative slide of the tumor with the highest nuclear grade was selected. VEGFA (Anti-VEGFA, sc-152; Santa Cruz Biotechnology, Santa Cruz, CA, USA) and CAIX 
(Anti-CAIX, ab15086, Abcam, Cambridge, UK) expressions were assessed by immunohistochemistry. The cut-off for positive cases was $30 \%$ of tumor cells for VEGF and $85 \%$ for CAIX as previously described [8-10]. Negative control was performed by omitting the primary antibody. Regarding tumor infiltrating lymphocytes, CD3 (anti-CD3, clone SP7, dilution 1/100; Thermo Scientific, Waltham, MA, USA) and CD20 (anti-CD20, clone L26, dilution 1/25; Dako, Glostrup, Denmark) expressions were assessed. The inflammatory extent was coded as 1 (sparse and rare lymphocytes) or 2 (marked dense lymphocytes or lymphoid nodules). The reactivity of antibodies was revealed with HRP-labeled polymer conjugated secondary antibodies using diaminobenzidine (Sigma-Aldrich, France). Tumor expressions were independently evaluated without knowledge of patient outcome or $V H L$ gene status (NRL).

\section{$\underline{V H L \text { gene analysis }}$}

The detection of VHL mutations was performed by sequencing in denaturing high performance liquid chromatography (DHPLC). We amplified two overlapping fragments for exon 1 (1A and 1B) and one fragment for each of exons 2 and 3, covering part of the $V H L$ 5'UTR, the entire coding sequence and exon-intron junctions (VHL Genbank accession AF010238) as previously described [11]. After purification, forward and reverse automatic sequencing was performed using BigDye Terminator v1.1 Cycling Sequencing kit on an ABI Prism 3100 Genetic Analyser (Applied Biosystems, Courtaboeuf, France). All mutations were confirmed in a second round of PCR and sequencing reactions.

Multiplex Ligation-dependent Probe Amplification (MLPA) analysis was used to detect deletions or duplications of the VHL gene with the SALSA MLPA P016B VHL probe kit (MRC-Holland, Amsterdam, Netherlands), targeting the three VHL exons. 
After denaturation and probe hybridization, PCR was performed and fragments were separated by electrophoresis on an Applied 3130XL capillary sequencer and quantified using the GeneMarker version 1.6 software (SoftGenetics). For copy number detection, normal control DNA samples were included in each set of MLPA experiments. Interpretation was based on the comparison of peak heights between control DNA and the tumor sample. Cut-off levels for loss of relative copy number were set at 0.75 .

Methylation-Specific-MLPA (MS-MLPA) was used to detect $\mathrm{CpG}$ methylation in the $V H L$ gene promotor [12]. The probe design containing a methylation-sensitive restriction site (HhaI) allowed detecting aberrant methylation of $\mathrm{CpG}$-islands located in the promoter region of the VHL gene using the SALSA MS-MLPA ME001B Tumor suppressor-1 kit.

Regarding tumor heterogeneity, we additionally performed $V H L$ studies in 10 patients, in different tumor regions, revealing the same $V H L$ status as initially described.

\section{$\underline{\text { Statistical analysis }}$}

Chi2 and Student's tests were performed to compare qualitative and quantitative parameters respectively between groups. Multivariate analysis was then performed. Cancer specific survival was compared by log rank test and represented with Kaplan Meier curves. All analyses were conducted by AP with the Stata 11.1 (College Station, TX) software and the pvalue significance was fixed at 0,05 . 


\section{RESULTS}

\section{$\underline{\text { Patients and histological parameters }}$}

The analysis retrospectively included 98 patients. The median age at diagnosis was 64 years (40-84). Sixty nine patients (70\%) had an ECOG performance status of 0 . In 11 cases (11.2\%), nodal invasion was present at diagnosis and 23 cases $(23.5 \%)$ had metastases. With time, 26 patients $(26.5 \%)$ developed metastases after initial diagnosis. Metastatic patients received diverse therapies including immunotherapies, tyrosine-kinase inhibitors, hormonotherapies, and classic chemotherapy. At a median follow-up of 64 months (0-139 months), 44 (44.9\%) subsequently died from their cancer and 51 (52\%) patients suffered from disease progression. The mean tumor size was $7.3 \mathrm{~cm}+/-3.4 \mathrm{~cm}$ with tumors ranging from 1.5 to $18 \mathrm{~cm}$. Population characteristics as well as pathological parameters are summarized in Table 1.

\section{Genetic and epigenetic VHL gene alteration}

All patients were negative for germ-line mutations. A $V H L$ gene mutation was found in 68 cases (69.4\%). Mutations occurred in exons 1, 2 and 3 in 27 (27.6\%), 27 (27.6\%) and 14 cases $(14.3 \%)$ respectively. Stop, frameshift, missense, and splice site mutations were found in $10(10.2 \%), 33(33.7 \%), 19(19.4 \%)$ and $6(6.1 \%)$ cases respectively. VHL loss of heterozygosity and promoter methylation occurred in 71 (72.4\%) and 13 cases $(13.3 \%)$ respectively. At least one or more VHL abnormalities were found in 87 cases $(88.8 \%)$. Tumors with 2 alterations of the $V H L$ gene ( $\mathrm{n}=65$ cases, $66.3 \%$ ) were termed inactivated for that gene $(i n V H L)$. Those with none or only one alteration $(n=33,33.7 \%)$ were grouped as activated $V H L$ tumors $(a c V H L)$. These included tumors with no alteration of the $V H L$ gene $(\mathrm{n}=11,11,2 \%)$ that were termed wild type $(w t V H L)$ (Figure 1$).$ 
acVHL tumors presented an aggressive clinical and pathological profile compared to ccRCCs with inVHL. Fuhrman grade $4(\mathrm{p}=0.02)$, metastasis $(\mathrm{p}=0.04)$, sarcomatoid component ( $p=0.03$ ), especially when estimated as $\geq 20 \% \quad(p=0.0006)$, dense lymphocyte infiltrate $(p=0.013)$ and overexpression of intratumoral VEGF $(p=0.0001)$ were significantly associated with acVHL ccRCCs (Tables 1 and 2). The overexpression of VEGF remained significant after multivariate analysis $(\mathrm{p}=0.004)$. Interestingly, lymph node metastases $(\mathrm{p}=0.019)$ was additionally associated with the subgroup of $w t V H L$. The expression of CAIX was not associated with any subgroup (mean expression: $88,9 \%$ for inVHL, $83 \%$ for acVHL and $74,3 \%$ for $w t V H L)$, even though the positive expression of VEGF in tumor cells was inversely correlated with the expression of CAIX ( $\mathrm{p}=0.002$, data not shown) (Figure 2).

\section{$\underline{\text { Relationship between } V H L \text { gene alterations and survival }}$}

While no significant difference was observed concerning specific survival rates between $a c V H L$ and inVHL cases $(\mathrm{p}=0.078)$, the subgroup of $w t V H L$ patients showed a separate evolution compared to both inVHL and patients with one $V H L$ alteration $(\mathrm{p}=0.016)$, and separately compared to inVHL patients $(\mathrm{p}=0.009)$. The survival curves of the 3 subgroups (inVHL, acVHL with one alteration, and $a c V H L$ with no alteration-wtVHL) are illustrated in Figure 3. Patients with wild type $V H L$ had the worse prognosis with a median specific survival of 33 months compared to patients with a $V H L$ gene inactivation who had a median specific survival of 82 months $(\mathrm{p}=0.035)$. 


\section{DISCUSSION}

This is the first study to our knowledge, with a long term clinical follow-up of ten years that deals with histological differences between ccRCCs depending on their complete VHL status. It shows the presence of three subgroups of tumors with different phenotypes and clinical outcomes. Clear cell renal cell carcinoma is a highly vascularized tumor, and the major gene implicated in its carcinogenesis at an early stage is $V H L$, a tumor suppressor gene that requires at least two events, one on each allele to be inactivated, as VHL is not a haploinsufficient tumor-suppressor gene. Deletion of the VHL gene locus was the most frequent event, $72.4 \%$ in our series which is less than the $91 \%$ loss of the $3 p$ region observed in a recent cancer genome study [13]. In this same study, mutations of the VHL gene were observed in $52 \%$ of cases and promoter hypermethylations in $7 \%$ of tumors. Theses events are reported in a variable percentage in the literature, between $34 \%$ and $71 \%$ for mutations [14,15], and between $5 \%$ and $19 \%$ for promoter hypermethylations [16,17]. We observed $69.4 \%$ and $14.2 \%$ of these events respectively. As expected, mutations and promoter methylations were mutually exclusive as no case exhibited the two events simultaneously. Mutations of the exons 1 and 2 were more frequent than those of exon 3 and frameshift mutations were the most common types of mutational events. Tumors with 2 VHL hits (inVHL (2)) represented $66.3 \%$ of patients, which was more frequent than tumors with only one hit (acVHL (1), 22.4\%) and even more frequent than tumors with no VHL event (wtVHL (0), $11.2 \%)$

VHL inactivation was associated with a better prognosis and this was illustrated by better survival rates, lower nuclear grade, less metastases, and less sarcomatoid component in this group of tumors than in acVHL tumors. Indeed, we observed that several factors were significantly associated with $a c V H L$ cases. In opposition to tumors with at least two alterations of the $V H L$ gene, $a c V H L$ tumors were associated with higher nuclear 4 grade and 
metastases. Sarcomatoid component was also more frequent in this group. This parameter is a major and well known poor prognostic factor [18], and our results are consistent with recent studies describing low HIF-1 $\alpha$ expression (due to a functional pVHL protein: $a c V H L$ ) in ccRCCs with a sarcomatoid component [19].

Dense lymphocyte infiltrate was associated with acVHL tumors. In ccRCC, the intra-tumoral mononuclear infiltrate is associated with pejorative outcomes and higher nuclear grade [2022]. For instance, binding of programmed death ligand 1 (PD-L1) expressed by tumor cells to the co-stimulatory receptor on $\mathrm{T}$ regulatory cells, $\mathrm{PD}-1$, promotes inactivation and apoptosis of activated tumor specific T lymphocytes, and blockade of PD-1 or its ligand PD-L1 by specific antibodies produce objective responses in some cancers including renal cell carcinomas [23-24]. This particularly dense lymphocyte infiltrate associated to acVHL tumors could be investigated looking for PD1-positive cells implicated in prognosis of ccRCCs and in PD1-based immunotherapy [25].

Surprisingly, the overexpression of VEGF was also independently associated with $a c V H L$ tumors and inversely correlated to the overexpression of CAIX. Both CAIX and VEGF are VHL/HIF downstream targets. However, unlike CAIX, which is a surrogate indicator for VHL status, VEGF regulation is much more complex. These results support the theory of alternative oncogenic pathways in ccRCC leading to VEGF overexpression despite HIF degradation due to the presence of an activated VHL protein $(a c V H L)$. Tumors with no inactivation of $V H L$ could use alternative pathways independent from $V H L$ mechanisms and lead to VEGF overexpression promoting tumor angiogenesis. These alternative pathways [2630], that include the MAP kinase and the PI3K-AKT-mTOR pathways, may be potentially implicated in the resistance to targeted therapy by tyrosine kinase inhibitors. 
Furthermore, the subgroup of $w t V H L$ tumors was clearly of worse prognosis as demonstrated by significant poorer specific survival rates. In our study, clinical outcomes did not significantly differ between the first two groups (inVHL and acVHL with one event). However, the group of patients with $w t V H L$ exhibited significant worse outcomes: $73 \%$ of $w t V H L$ patients died from their cancer at the end of follow-up, compared to $45 \%$ of patients with one $V H L$ alteration and $40 \%$ of patients with inVHL tumors.

The limitations to this study, besides the small number of wild type cases, are the variation of treatment given to metastatic patients at the time before full market approval of proteintyrosine kinase inhibitors as a first-line drug; similarly to all studies realized on kidney cancer at that time. The other limitation is the high frequency of metastatic patients in the wild type group, disabling us from excluding metastatic patients from the analysis, and which does not allow a metastatic-independent evaluation of mortality.

\section{CONCLUSIONS}

This study shows the existence of three groups of ccRCCs depending on their VHL status. The $w t V H L$ subgroup is a separate entity of worse prognosis. The wider perspective of this study is to increase these cases that represent only $10 \%$ of ccRCCs for a better molecular characterization and the study of wtVHL tumors in non-metastatic patients. Such an increase would enable us to dig further in what makes these tumors so specific and more aggressive, and in why VEGF remains at high levels of expression, despite a VHL protein that is intact. These tumors could be screened more thoroughly and studied as factors of resistance or sensitivity to targeted therapy. Other types of specific therapies targeting alternative pathways of VEGF may be useful in treating these patients. 


\section{Ackwoledgments}

The authors would like to acknowledge the Ligue Contre le Cancer, the CORECT, Rennes Hospital and the French Institute of Cancer (INCa) for their financial aid.

The authors would also like to thank the Center of Biological Resources of Rennes Hospital for the conservation of tumor specimens; as well as the Histopathology platform $\mathrm{H} 2 \mathrm{P} 2$ BIOSIT from the Faculty of Medicine of Rennes for their technical support. 


\section{REFERENCES}

1. In: Eble JN, Sauter G, Epstein JI, Sesterhenn IA editor. World Health Organization classification of tumours. Pathology and genetics of tumours of the urinary system and male genital organs. Lyon, France: IARC Press; 2004; p.12-1723-25.

2. Gnarra JR, Tory K, Weng Y et al. Mutations of the VHL tumour suppressor gene in renal carcinoma. Nat Genet. 1994;7(1):85-90.

3. Kim WY, Kaelin WG. Role of VHL gene mutation in human cancer. J Clin Oncol. 2004;22(24):4991-5004.

4. Barnabas N, Amin MB, Pindolia K, Nanavati R, Amin MB, Worsham MJ. Mutations in the von Hippel-Lindau (VHL) gene refine differential diagnostic criteria in renal cell carcinoma. J Surg Oncol. 2002;80(1):52-60.

5. Kaelin WG Jr. The von Hippel-Lindau tumor suppressor protein and clear cell renal carcinoma. Clin Cancer Res. 2007;13(2 Pt 2):680s-684s.

6. Oken MM, Creech RH, Tormey DC, et al. Toxicity and response criteria of the Eastern Cooperative Oncology Group. Am J Clin Oncol. 1982;5(6):649-55.

7. Edge SB, Compton CC. The American Joint Committee on Cancer: the 7th edition of the AJCC cancer staging manual and the future of TNM. Ann Surg 2010 Oncol.17(6):1471-4

8. Jacobsen J, Grankvist K, Rasmuson T, Bergh A, Landberg G, Ljungberg B. Expression of vascular endothelial growth factor protein in human renal cell carcinoma. BJU Int. 2004;93(3):297-302. 
9. Patard JJ, Fergelot P, Karakiewicz PI, et al. Low CAIX expression and absence of VHL gene mutation are associated with tumor aggressiveness and poor survival of clear cell renal cell carcinoma. Int J Cancer. 2008;123(2):395-400.

10. Rioux-Leclercq N, Fergelot P, Zerrouki S, et al. Plasma level and tissue expression of vascular endothelial growth factor in renal cell carcinoma: a prospective study of 50 cases. Hum Pathol. 2007;38(10):1489-95.

11. Patard JJ, Rioux-Leclercq N, Masson D, et al. Absence of VHL gene alteration and high VEGF expression are associated with tumour aggressiveness and poor survival of renalcell carcinoma. Br J Cancer. 2009;101(8):1417-24.

12. Jeuken JW, Cornelissen SJ, Vriezen M, et al. MS-MLPA: an attractive alternative laboratory assay for robust, reliable, and semiquantitative detection of MGMT promoter hypermethylation in gliomas. Lab Invest.2007; 87(10):1055-65.

13. Cancer Genome Atlas Research Network. Comprehensive molecular characterization of clear cell renal cell carcinoma. Nature.2013; 499(7456):43-9.

14. Schraml P, Struckmann K, Hatz F, et al. VHL mutations and their correlation with tumour cell proliferation, microvessel density, and patient prognosis in clear cell renal cell carcinoma. J Pathol. 2002;196(2):186-93.

15. Banks RE, Tirukonda P, Taylor C, et al. Genetic and epigenetic analysis of von Hippel-Lindau (VHL) gene alterations and relationship with clinical variables in sporadic renal cancer. Cancer Res. 2006;66(4):2000-11.

16. Kondo K, Yao M, Yoshida M, et al. Comprehensive mutational analysis of the VHL gene in sporadic renal cell carcinoma: relationship to clinicopathological parameters. Genes Chromosomes Cancer. 2002;34(1):58-68. 
17. Herman JG, Latif F, Weng Y, et al. Silencing of the VHL tumor-suppressor gene by DNA methylation in renal carcinoma. Proc Natl Acad Sci U S A. 1994;91(21):9700-4.

18. Kwak C, Park YH, Jeong CW, et al. Sarcomatoid differentiation as a prognostic factor for immunotherapy in metastatic renal cell carcinoma. J Surg Oncol. 2007;95(4):317-23.

19. Ku JH, Park YH, Myung JK, Moon KC, Kwak C, Kim HH. Expression of hypoxia inducible factor- $1 \alpha$ and $2 \alpha$ in conventional renal cell carcinoma with or without sarcomatoid differentiation. Urol Oncol. 2011;29(6):731-7.

20. Nakano O, Sato M, Naito Y, et al. Proliferative activity of intratumoral CD8(+) Tlymphocytes as a prognostic factor in human renal cell carcinoma: clinicopathologic demonstration of antitumor immunity. Cancer Res. 2001;61(13):5132-6.

21. Webster WS, Lohse CM, Thompson RH, et al. Mononuclear cell infiltration in clearcell renal cell carcinoma independently predicts patient survival. Cancer. 2006;107(1):46-53.

22. Pittet MJ. Behavior of immune players in the tumor microenvironment. Curr Opin Oncol. 2009;21(1):53-9.

23. Brahmer JR, Tykodi SS, Chow LQ, et al. Safety and activity of anti-PD-L1 antibody in patients with advanced cancer. N Engl J Med. 2012;366(26):2455-65.

24. Topalian SL, Hodi FS, Brahmer JR, et al. Safety, activity, and immune correlates of anti-PD-1 antibody in cancer. N Engl J Med. 2012;366(26):2443-54.

25. Kang MJ, Kim KM, Bae JS, et al. Tumor-infiltrating PD1-Positive Lymphocytes and FoxP3-Positive Regulatory T Cells Predict Distant Metastatic Relapse and Survival of Clear Cell Renal Cell Carcinoma. Transl Oncol. 2013;6(3):282-9. 
26. Edeline J, Vigneau C, Patard JJ, Rioux-Leclercq N. [Signalling pathways in renal-cell carcinoma: from the molecular biology to the future therapy]. Bull Cancer. 2010;97:5-15.

27. Pécuchet N, Fournier LS, Oudard S. New insights into the management of renal cell cancer. Oncology. 2013;84(1):22-31.

28. Huang D, Ding Y, Zhou M, et al. Interleukin-8 mediates resistance to antiangiogenic agent sunitinib in renal cell carcinoma. Cancer Res. 2010;70(3):1063-71.

29. Swanton C, Larkin JM, Gerlinger M, et al. Predictive biomarker discovery through the parallel integration of clinical trial and functional genomics datasets. Genome Med. 2010;2(8):53.

30. Rini BI, Atkins MB. Resistance to targeted therapy in renal-cell carcinoma. Lancet Oncol. 2009;10(10):992-1000. 


\section{FIGURE LEGENDS}

Table 1. Summary of the clinical, histological and immunohistochemical characteristics of the 98 patients and those with 0-1 VHL events.

The histological prognostic factors were assessed for each tumor. Pathological diagnosis is according to Fuhrman's grading system and UICC tumor-node-metastasis staging system. Values are presented as median (minimum - maximum) for continuous variables and number of patients (percentage) for categorical variables. The immunoexpression of VEGF and CAIX were considered positive if the percentage of stained tumor cells was above a defined threshold of $30 \%$ and $85 \%$ respectively. The inflammatory extent was coded as 1 (sparse or rare lymphocytes around the tumor) or as 2 (marked dense lymphocytes or lymphoid nodules).

Figure1. Results of the complete $V H L$ gene status of the 98 ccRCC patients.

VHL gene mutations are mutually exclusive to promoter hypermethylations.

(n): number of events affecting the $V H L$ gene.

Table 2. Associations between $V H L$ gene status and morphological parameters (Chi 2 test)

Activated $V H L$ ( 0 or 1 event) tumors were significantly associated to metastases $(\mathrm{p}=0.043)$, higher Fuhrman grade $4(\mathrm{p}=0.02)$, sarcomatoid component $(\mathrm{p}=0.03)$, dense lymphocyte infiltrate $(\mathrm{p}=0.013)$ and VEGF overexpression $(\mathrm{p}=0.0001)$ compared to inactivated $V H L$ tumors (2 events).

** VEGF expression was an independent factor after multivariate analysis. 
Figure 2. ccRCC pathological parameters associated with functional VHL gene (ac VHL or $w t V H L)$.
A) ccRCC with Fuhrman grade 4 (x 40);
B) ccRCC with sarcomatoid component (x 40);
C) ccRCC with a dense lymphocyte infiltrate (x10);
D) ccRCC with diffuse and strong cytoplasmic VEGF immunostaining (x 40).

Figure 3. ccRCC specific survivals according to $V H L$ gene status.

inVHL (2) vs. [acVHL (1) \& wtVHL (0)]: $\mathrm{p}=0.078$

$w t V H L(0) v s .[\operatorname{inVHL}(2) \& \operatorname{acVHL}(1)]: \mathbf{p}=\mathbf{0 . 0 1 6}$

$w t V H L(0) v s . \operatorname{in} V H L(2): \mathbf{p}=\mathbf{0 . 0 0 9}$

$w t V H L$ : wild type VHL tumors with no alteration of the gene (0 event). acVHL : activated VHL tumors with one alteration of the gene (1 event). inVHL: inactivated VHL tumors with 2 alterations of the gene ( 2 events). 
Table 1 - Summary of the clinical, histologic, and immunohistochemical characteristics of the 98 patients and those with no or one von Hippel-Lindau tumor suppressor events

\begin{tabular}{|c|c|c|}
\hline & $\begin{array}{l}\text { Patients } \\
(n=98)\end{array}$ & $\begin{array}{c}\text { Patients with no or } \\
\text { one event }(n=33)\end{array}$ \\
\hline \multicolumn{3}{|l|}{ Sex } \\
\hline Female & $38(38.8)$ & $13(39.4)$ \\
\hline Male & $60(61.2)$ & $20(60.6)$ \\
\hline \multicolumn{3}{|c|}{ Tumor size, $\mathrm{cm}$} \\
\hline Median (range & $7.3(1.5-18)$ & $7.8(2-13)$ \\
\hline \multicolumn{3}{|c|}{ Fuhrman grade } \\
\hline II & $35(35.7)$ & $9(27.3)$ \\
\hline III & $32(32.7)$ & $8(24.2)$ \\
\hline IV & $31(31.6)$ & $16(48.5)$ \\
\hline \multicolumn{3}{|l|}{ Tumor stage } \\
\hline 1 & $37(37.8)$ & $10(30.3)$ \\
\hline 2 & $18(18.4)$ & $6(18.2)$ \\
\hline 3 & $39(39.8)$ & $14(42.4)$ \\
\hline 4 & $4(4.1)$ & $3(9.1)$ \\
\hline \multicolumn{3}{|c|}{ Lymph node status } \\
\hline 0 & $87(88.8)$ & $29(87.9)$ \\
\hline 1 or 2 & $11(11.2)$ & $4(12.1)$ \\
\hline \multicolumn{3}{|c|}{ Metastasis status } \\
\hline 0 & $75(76.5)$ & $21(63.6)$ \\
\hline 1 & $23(23.5)$ & $12(36.4)$ \\
\hline \multicolumn{3}{|c|}{ Tumor necrosis } \\
\hline Present & $53(54.1)$ & $17(51.5)$ \\
\hline Absent & $45(45.9)$ & $16(48.5)$ \\
\hline \multicolumn{3}{|c|}{ Sarcomatoid component } \\
\hline Present & $15(15.3)$ & $9(27.3)$ \\
\hline Absent & $83(84.7)$ & $24(72.7)$ \\
\hline \multicolumn{3}{|c|}{ Granular component } \\
\hline Present & $51(52)$ & $19(57.6)$ \\
\hline Absent & $47(48)$ & $14(42.4)$ \\
\hline \multicolumn{3}{|c|}{ Microvascular invasion } \\
\hline Present & $39(39.8)$ & $14(42.4)$ \\
\hline Absent & $59(60.2)$ & $19(57.6)$ \\
\hline \multicolumn{3}{|c|}{ Lymphocyte infiltrate } \\
\hline 1 & $84(85.7)$ & $24(72.7)$ \\
\hline 2 & $14(14.3)$ & $9(27.3)$ \\
\hline \multicolumn{3}{|l|}{ VEGF } \\
\hline$\geq 30 \%$ & $59(60.2)$ & $27(81.8)$ \\
\hline$<30 \%$ & $39(39.8)$ & $6(18.2)$ \\
\hline \multicolumn{3}{|l|}{ CAIX } \\
\hline$\geq 85 \%$ & $74(75.5)$ & $24(72.7)$ \\
\hline$<85 \%$ & $24(24.5)$ & $9(27.3)$ \\
\hline
\end{tabular}




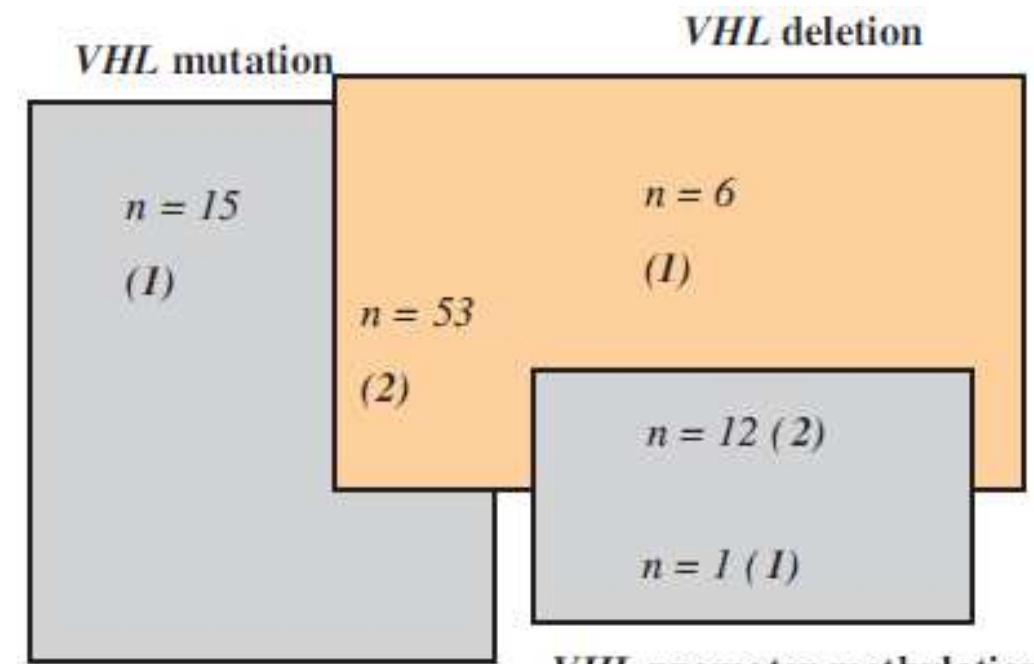

$V H L$ promoter methylation

Wild-type $V \boldsymbol{H L}$

$n=11$

(0)

Fig. 1 - Results of the complete VHL gene status of the 98 patients with clear cell renal cell carcinoma. VHL gene mutations are mutually exclusive to promoter hypermethylations. Parentheses indicate the number of events affecting the VHL gene. 
Table 2 - Associations between VHL gene status and morphologic parameters

$$
\begin{array}{lcl}
\underset{(n=33)}{n i V H L} & \text { inVHL } & p \text { value }
\end{array}
$$

\begin{tabular}{|c|c|c|c|}
\hline \multicolumn{4}{|c|}{ T stage } \\
\hline $\mathrm{T} 3 / \mathrm{T} 4$ vs $\mathrm{T} 1 / \mathrm{T} 2$ & $17(51.5)$ & $26(40)$ & 0.29 \\
\hline \multicolumn{4}{|l|}{$\mathrm{N}$ stage } \\
\hline $\mathrm{N} 1 / \mathrm{N} 2$ vs NO & $4(12.1)$ & $7(10.8)$ & 1 \\
\hline \multicolumn{4}{|l|}{ M stage } \\
\hline M1 vs M0 & $12(36.4)$ & $11(16.9)$ & 0.043 \\
\hline \multicolumn{4}{|l|}{ Fuhrman grade } \\
\hline Grade IV vs grades I-III & $16(48.5)$ & $15(23.1)$ & 0.02 \\
\hline \multicolumn{4}{|l|}{ Microvascular invasion } \\
\hline Present vs absent & $14(42.4)$ & $25(38.5)$ & 0.8 \\
\hline \multicolumn{4}{|l|}{ Granular component } \\
\hline Present vs absent & $19(57.6)$ & $32(49.2)$ & 0.2 \\
\hline \multicolumn{4}{|l|}{ Sarcomatoid component } \\
\hline Present vs absent & $9(27.3)$ & $6(9.2)$ & 0.03 \\
\hline \multicolumn{4}{|l|}{ Tumor necrosis } \\
\hline Present vs absent & $17(51.5)$ & $36(55.4)$ & 0.83 \\
\hline \multicolumn{4}{|l|}{ Lymphocyte infiltrate } \\
\hline Present vs absent & $9(27.3)$ & $5(7.7)$ & 0.013 \\
\hline \multicolumn{4}{|l|}{ Hemorrhagic zone } \\
\hline Present vs absent & $25(75.8)$ & $55(84.6)$ & 0.28 \\
\hline \multicolumn{4}{|l|}{ VEGF $\S$} \\
\hline $\begin{array}{l}\text { Overexpression vs } \\
\text { no expression }\end{array}$ & $27(81.8)$ & $32(49.2)$ & 0.0001 \\
\hline \multicolumn{4}{|l|}{ CAIX } \\
\hline $\begin{array}{l}\text { Overexpression vs } \\
\text { no expression }\end{array}$ & $24(72.7)$ & $50(76.9)$ & 0.8 \\
\hline \multicolumn{4}{|c|}{$\begin{array}{l}\text { CAIX = carbonic anhydrase IX; VEGF = vascular endothelial growth factor; } \\
\text { VHL }=\text { von Hippel-Lindau tumor suppressor gene. } \\
\text { Data are shown as number (percentage). } \\
\text { Chi-square test. } \\
\text { Noninactivated VHL ( } 0 \text { or } 1 \text { event) tumors were significantly associated to } \\
\text { metastases }(p=0.043 \text { ), higher Fuhrman grade } 4(p=0.02) \text {, sarcomatoid } \\
\text { component }(p=0.03) \text {, dense lymphocyte infiltrate }(p=0.013 \text { ), and VEGF } \\
\text { overexpression }(p=0.0001) \text { compared to inactivated VHL tumors (two } \\
\text { events). } \\
\$ \text { Bolded } p \text { values indicate significance at } \leq 0.05 \text {. } \\
\S \text { VEGF expression was an independent factor after multivariate analysis. }\end{array}$} \\
\hline
\end{tabular}



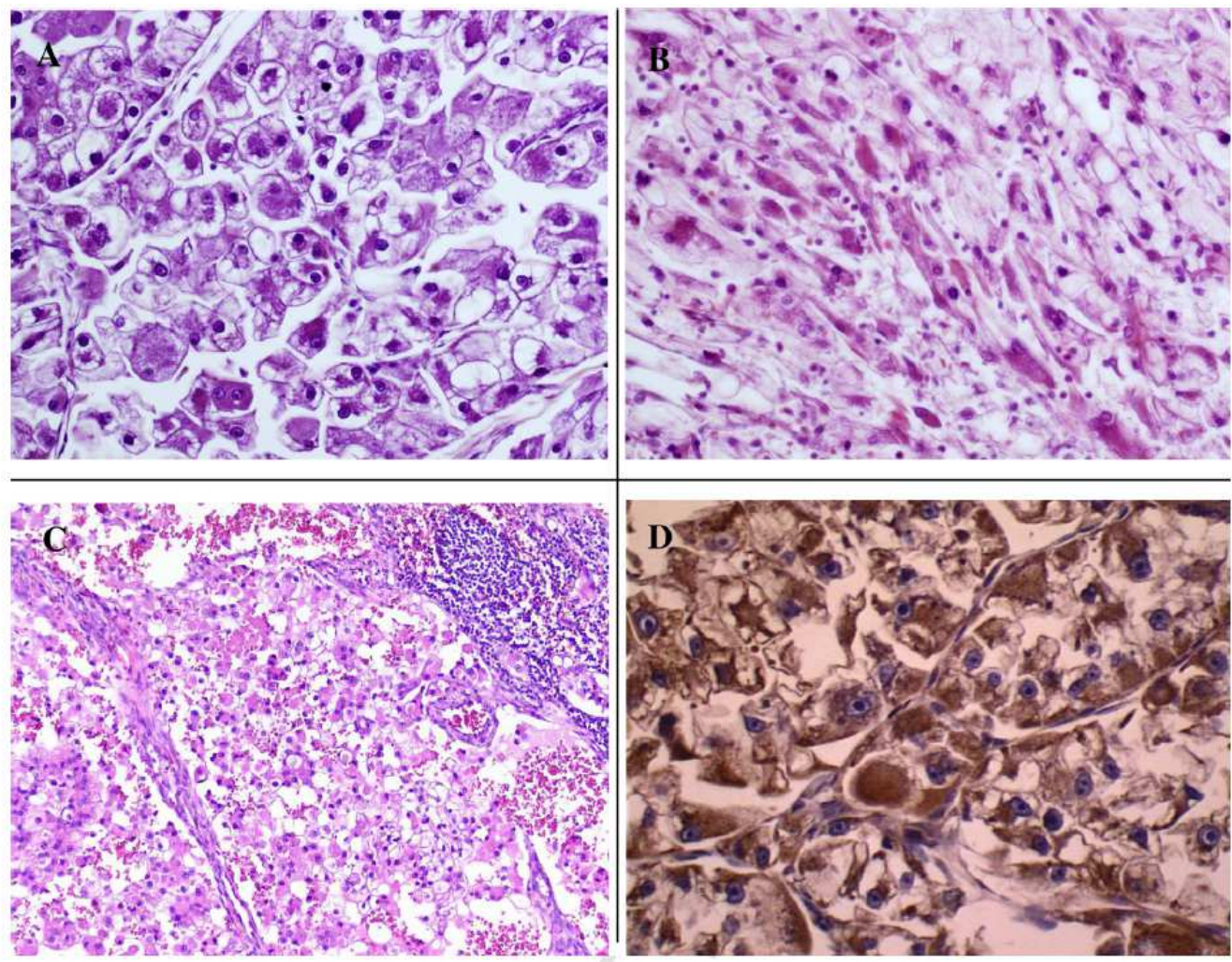

Fig. 2 - Clear cell renal cell carcinoma (ccRCC) pathologic parameters associated with functional VHL gene (noninactivated VHL or wild-type VHL). All micrographs taken at $\times \mathbf{4 0}$ magnification. (A) ccRCC with Fuhrman grade IV; (B) ccRCC with sarcomatoid component; (C) ccRCC with a dense lymphocyte infiltrate; (D) ccRCC with diffuse and strong cytoplasmic vascular endothelial growth factor immunostaining. 


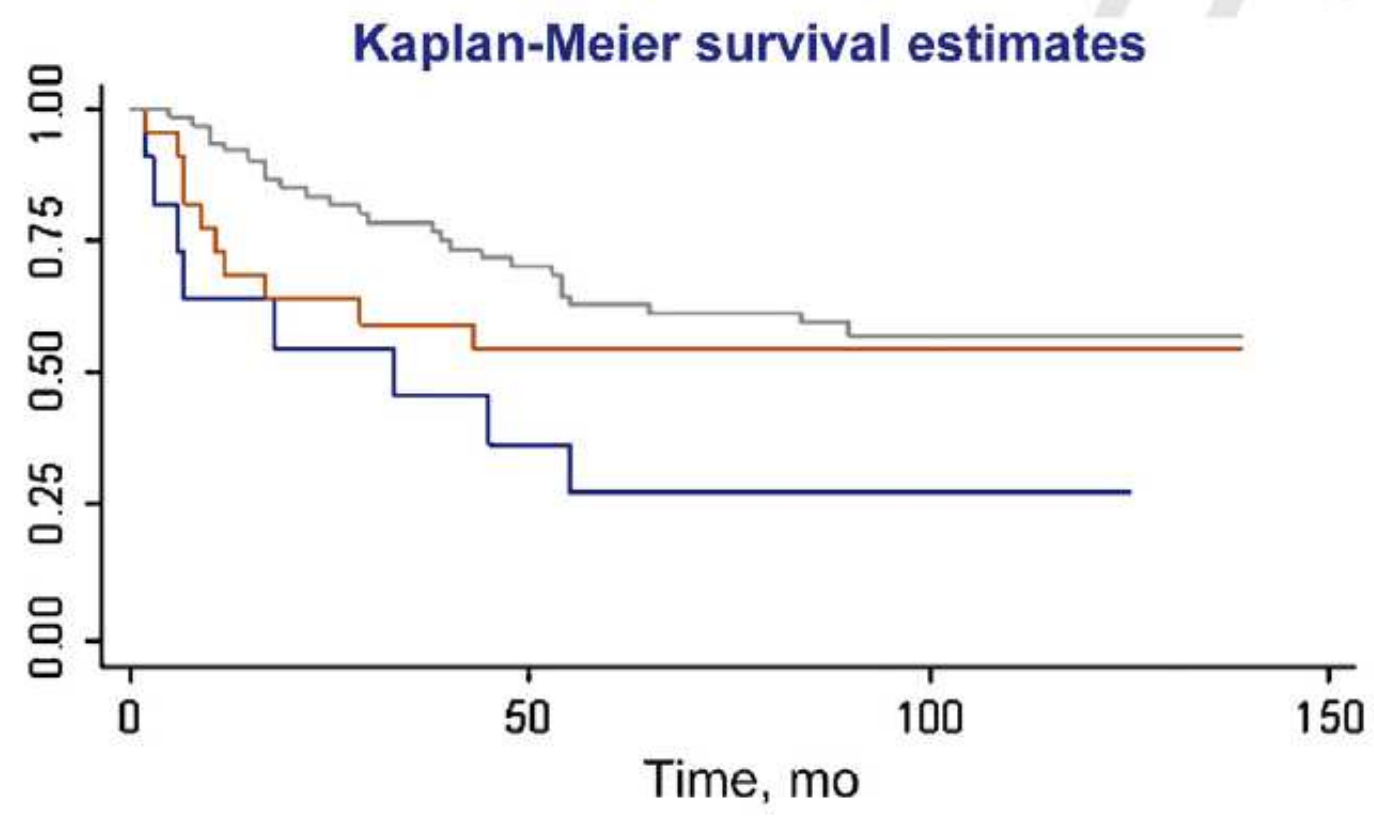

$$
\begin{aligned}
& -\operatorname{wtVHL}(0)-\operatorname{niVHL}(1) \\
& -\operatorname{in} V H L \text { (2) }
\end{aligned}
$$

Fig. 3 - Clear cell renal cell carcinoma-specific survival according to $V H L$ gene status: inVHL (2) versus niVHL (1) and wtVHL (0): $p=0.078$; wtVHL (0) versus inVHL (2) and niVHL (1): $p=0.016$; wtVHL (0) versus inVHL (2): $p=0.009$.

inVHL (2) = inactivated VHL tumors with two alterations of the gene (ie, two events); niVHL (1) = noninactivated VHL tumors with one alteration of the gene (ie, one event); wtVHL $(0)=$ wild-type VHL tumors with no alteration of the gene (ie, no events). 